\title{
Rencana Strategi Teknologi Informasi pada Perguruan Tinggi di Indonesia: Sebuah Tinjauan Pustaka
}

\author{
Wahyudi Agustiono*, Mutiara Cahyani Fajrin, Fika Hastarita Rachman \\ Teknik Informatika, Fakultas Teknik, Universitas Trunojoyo Madura \\ Jl. Raya Telang PO BOX 2 Kamal Bangkalan \\ *e-mail: wahyudi.agustiono@trunojoyo.ac.id
}

(received: 26 November 2020, revised: 13 Januari 2021, accepted: 16 Januari 2021)

\begin{abstract}
Abstrak
Teknologi Informasi (TI) salah satu bagian penting dalam sebuah organisasi. Terutama pada era disrupsi dan lingkungan yang dinamis saat ini, TI telah menjadi sarana utama bagi organsisasi untuk mencapai efisiensi dalam operasional dan mendapatkan keunggulan kompetitif. Oleh karena itu, perencanaan strategis TI yang efektif sangat diperlukan guna memastikan bahwa proses pembangunannya sejalan dengan nilai, visi, misi dan tujuan dari organisasi. Hal ini tanpa perkecualian bagi universitas sebagai salah satu organisasi pendidikan yang saat ini semakin mengandalkan TI untuk memfasilitasi penyelenggaraan kegiatan akademis yang berkualitas serta memberikan layanan terbaik bagi para pemangku kepentingan. Dalam penelitian ini dilakukan kajian pustaka terhadap 34 artikel yang berkaitan dengan perencanaan strategi TI pada perguruan tinggi di Indonesia. Dari 34 artikel dibagi menjadi 2 sub topik perencanaan strategi TI. Dari hasil kajian pada 34 artikel diperoleh temuan yang mendominasi penelitian, yaitu terdapat sebanyak 30 artikel yang membahas topik penelitian mengenai kegiatan perencanaan strategi TI, 17 artikel yang menggunakan framework Ward And Peppard, 22 perguruan tinggi swasta yang dijadikan objek penelitian, 34 artikel yang melakukan perencanaan strategi TI sebagai aspek penelitian, dan kurangnya jumlah penelitian mengenai tingkat keselarasan antara perencanaan strategi TI dan strategi bisnis, serta kurangnya penelitian mengenai perencanaan strategi TI pada perguruan tinggi negeri di Indonesia.
\end{abstract}

Kata Kunci: Tinjauan Pustaka, Perencanaan Strategis TI, Teknologi Informasi, Perguruan tinggi

\begin{abstract}
Information Technology (IT) is an essential part for many organisations. Especially in the current disruptive and dynamic environment, IT has been the main tool for achieving operational efficiencies and gain competitive advantage. Indeed, an effective IT strategic plan is required to ensure the development is inline with the organisations' value, vision, mission and goals. This is no exception for university as a learning organisation which is becoming more reliant on IT in facilitating a quality academic activites and providing excellent servics to its stakeholders. In this study, a review was conducted of 34 articles related to the strategic planning of information technology in Indonesian universities. From 34 articles divided into 2 sub topics information technology strategic planning. From the results of the study on 34 articles, it was found that the findings dominated the research, namely 30 articles that discussed research topics regarding IT strategic planning activities, 17 articles using the Ward And Peppard framework, 22 private universities that were used as research objects, 34 articles that carried out planning IT strategy as an aspect of research, and the lack of research on the level of alignment between IT strategy planning and business strategy, as well as a lack of research on IT strategy planning in state universities in Indonesia.
\end{abstract}

Keywords: literature review, IT strategic plan, information teknologi

\section{Pendahuluan}

Saat ini, Teknologi Informasi (TI) telah menjadi bagian utama dan tidak terpisahkan bagi sebuah organisasi. Terlebih di era revolusi industri 4.0, dimana TI tidak hanya menjadi alat utama, akan tetapi juga sebagi acuan dari kemajuan sebuah organisasi. Untuk memastikan bahawa setiap upaya 
pengembangan TI sesuai dengan tujuan organisasi, maka harus disertai dengan Perencanaan Strategis TI (PSTI). Menurut Osten seperti yang dikutip dalam Handayani [1], PSTI adalah usaha untuk menyelaraskan penggunaan teknologi informasi ke dalam misi organisasi. PSTI tidak hanya fokus pada pengembangan teknologi, namun mengenai bagaimana sebuah teknologi dapat mempengaruhi perkerjaan, infrastruktur maupun hubungan antar manusia dalam organisasi. Dengan adanya PSTI akan membantu dan menjamin keberhasilan pembanguan TI sesuai dengan tujuan yang telah direncanakan.

Menurut Harold Kerzner seperti yang dikutip oleh Bachtiar dan Hasanah [2], penerapan TI yang tidak terencana dan terkelola dengan baik akan menyebabkan meruginya organisasi, sumber daya TI yang ada tidak akan selaras dengan tujuan organisasi. Selain membutuhkan investasi yang mahal, membangun teknologi informasi membutuhkan teknologi yang rumit dan lebih maju atau bahkan terbaru, sehingga pembangunan teknologi informasi akan semakin sulit tanpa ada suatu perencanaan sebelumnya. Adapun manfaat-manfaat penerapan perencanaan strategi teknologi informasi bagi organisasi adalah sebagai berikut:

1. Dapat digunakaan sebagai landasan pembangunan organisasi dalam implementasi teknologi informasi yang terstruktur dan terarah.

2. Meminimalisir kemungkinan munculnya resiko yang dapat mengganggu proses pembangunan teknologi informasi.

3. Dapat digunakan sebagai acuan ataupun parameter keberhasilan pembangunan teknologi informasi pada organisasi.

Sebagai organisasi yang bergerak di bidang pendidikan, perguruan tinggi juga menghadapi tantangan dalam menyediakan layanan akademis berbasis TI. Dalam menghadapi persaingan tersebut perguruan tinggi dituntut untuk menyediakan data secara cepat dan akurat dalam pengambilan keputusan yang mampu mendorong pengelolaan lembaga pendidikan menggunakan pendekatan berbasis TI. Oleh karena itu PSTI bagi sebuah perguruna tinggi juga sangat penting agar tidak hanya menjamin suksesnya rencana pembanguan IT tapi juga dapat merealisasikan tujuan sesuai prinsip tri dharma perguruan tinggi. Penelitian sebelumnya telah membahas PSTI di perguruan tinggi .Namun dengan semakin meningkatnya jumlah penelitian membuat kesulitan bagi perguruan tinggi dalam menentukan pedekatan, model dan kerangka kerja dalam pembuatan PSTI.

Berdasarkan permasalahan yang telah dipaparkan diatas, tujuan dari penelitian ini adalah untuk melakukan kajian pustaka secara sistematis terhadap penelitian sebelumnya mengenai PSTI pada konteks perguruan tinggi. Hasil dari penelitian ini akan memberikan kontribusi terutama pengetahuan tentang fokus penelitian PSTI terdahulu di lingkup perguruan tinggi dan mengetahui hal-hal yang belum dikerjakan pada saat ini. Maka diharapkan hasil dari kajian pustaka dari penelitian ini dapat digunakan sebagai acuan penelitian selanjutnya mengenai perencanaan strategi teknologi informasi terutama pada perguruan tinggi di Indonesia.

\section{Tinjauan Literatur}

Sebagaimana yang telah dibahas di atas tentang pentingnya TI bagi institusi pendidikan, banyak peneliti dalam bidang sistem informasi tertarik untuk menjadikan PSTI pada perguruan tinggi sebagai objek penelitian. Dalam membuat PSTI, para peneliti menggunakan berbagai macam pendekatan, teknik pengambilan data, kasus, metode dan cara melakukan analisis, Sebagai contoh, ada berbagai macam kerangka kerja yang digunakan di dalam PSTI antara lain COBIT 5 [3], Ward and Peppard [4], IT Balanced Scorecard [5] dan SAMM [6]. Bahkan beberapa peneliti mencoba menggunakan kombinasi kerangka kerja untuk membantu menghasilkan PSTI yang lebih akurat seperti TOGAF dan Pemodelan ADM [7]; COBIT 5 dengan Ward and Peppard [8]; dan Enterprise Architecture (EA) dengan TOGAF [9].

Selain menggunakan berbagai macam kerangka kerja, para peneliti juga mengadopsi beragam metode analisis tematik untuk mendapatkan informasi yang berguna dalam penyusunan PSTI. Salah satu metode yang paling populer yang sering digunakan oleh para peneliti dalam menganalisis data yaitu dengan pendekatan Strength Weak Opportunity and Threat (SWOT) [4, 10]. Metode analisis lain yang juga digunakan antara lain Porters Five Forces, SWOT, CSF, Value Chain dan McFarlan 
Strategic Analysis $[5,11,12]$. Di dalam studi mereka, para peneliti umumnya mencoba memanfaatkan kombinasi dari metode tersebut di atas untuk membantu menganalisis data dan menghasilkan informasi yang berguna untuk meyusun PSTI secara tepat.

Namun dengan banyaknya penelitian mengenai topik perencanaan strategi teknologi informasi pada perguruan tinggi membuat para peneliti melakukan penelitian baru tentang topik tersebut kesulitan menentukan pendekatan, model ataupun kerangka kerja yang akan diterapkan. Hal ini juga dapat menyulitkan para praktisi TI yang mencoba membangun teknologi informasi pada perguruan tinggi. Terutama dalam hal menentukan apa metode yang paling sesuai, siapa kontributor dan pendukung, cara penyusunan perencanaan strategi teknologi informasi yang dapat dimanfaatkan dalam mewujudkan tujuan perguruan tinggi. Sementara itu hasil kajian pustaka menunjukkan belum ada peneliti yang telah melakukan analisis dan informasi apa saja kerangka kerja yang paling banyak digunakan, sspek apa saja yang dilakukan penyusunan perencanaan serta apa saran untuk penelitian di masa dating terutama terkait PSTI di perguruan tinggi.

\section{Metode Penelitian}

Metode penelitian yang digunakan dalam studi ini yaitu Systematic Literature Review (SLR) berdasarkan penelitian sebelumnya [13] yang terdiri dari 8 tahapan. Dari ke-8 tahapan SLR disederhanakan menjadi 3 tahapan sesuai yang disarankan oleh Adrian dkk. [14]. Gambar 1 menunjukkan metode penelitian yang diadopsi pada artikel ini yang terdiri dari 3 tahapan. Pada tahapan yang pertama berupa perencanaan, yaitu dengan menetapkan konteks pencarian, mendefinisikan protokol tinjauan dan merumuskan daftar pertanyaan dalam penelitian. Tahapan yang kedua adalah tahap pelaksanaan, yaitu tahapan melaksanakan pencarian dan melakukan ekstraksi data sebagai proses dalam mengelompokkan setiap item sebagai hasilnya. Dan tahap ketiga adalah pelaporan, dimana dalam tahapan ini disimpulkan hasil penelitian serta dikemukakan.

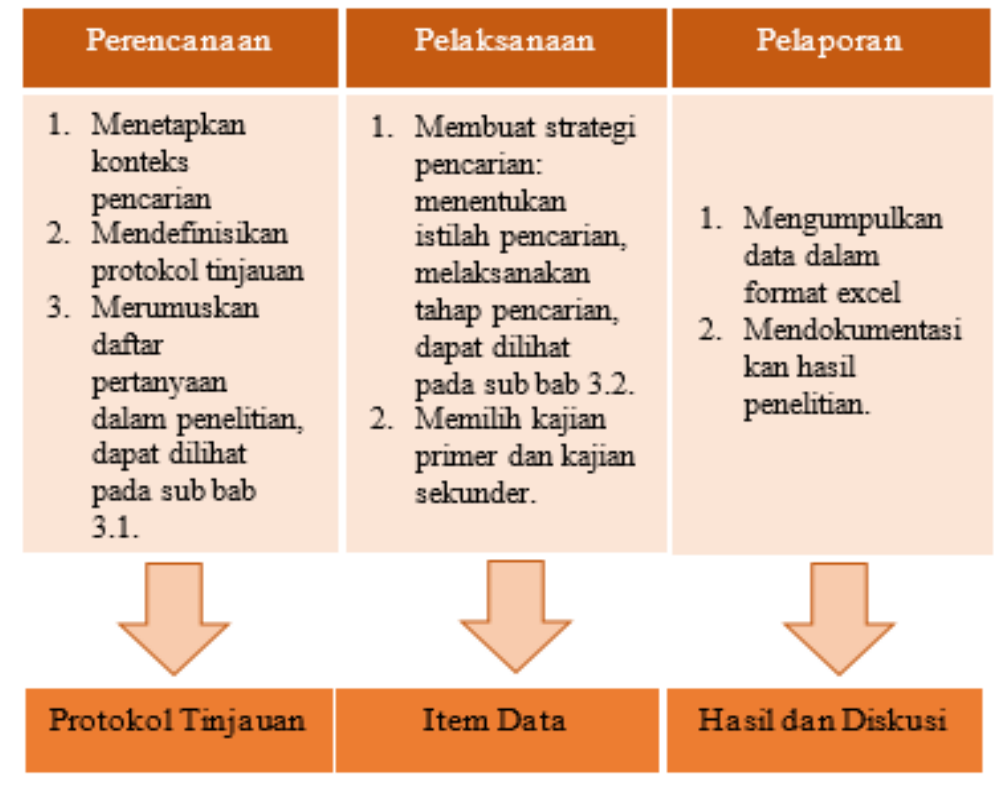

Gambar 1. Tahapan Systematic Literature Review

\section{1 Pertanyaan Penelitian (Research Question)}

Pada tahap perencanaan penelitian ini kriteria pertanyaan disusun menggunakan PICOC (Population, Intervention, Comparison, Outcomes and Context). Ruang lingkup pertanyaan pada penelitian ini dapat dilihat pada Tabel 1. 
Tabel 1. Ruang Lingkup Pertanyaan Penelitian

\begin{tabular}{lll}
\hline \multicolumn{1}{c}{ Kriteria } & \multicolumn{3}{c}{ Cakupan } \\
\hline Populasi & Perencanaan strategi IT pada Perguruan Tinggi (PT) \\
Intervensi & Batasan pada penelitian mengenai perencanaan strategi IT pada PT \\
Komparasi & Tidak tersedia \\
Hasil & Aspek penilaian perencanaan strategi IT pada perguruan tinggi, kerangka \\
Konteks & Tinjauan tentang semua penelitian mengenai perencanaan strategi IT pada PT \\
\hline
\end{tabular}

Berdasarkan Tabel 1 tersebut dapat disusun lima pertanyaan penelitian (RQ) antara lain:

1. RQ1: Apa saja topik penelitian mengenai perencanaan strategi IT pada perguruan tinggi?

2. RQ2: Apa saja kerangka kerja/framework yang digunakan pada perencanaan strategi IT pada perguruan tinggi?

3. RQ3: Perguruan tinggi mana yang dijadikan objek penelitian perencanaan strategi IT?

4. RQ4: Aspek apa saja yang dilakukan penyusunan perencanaan strategi IT pada perguruan tinggi?

5. RQ5: Penelitian apa yang kurang dilakukan dan perlu pengembangan?

\section{2 Strategi Pencarian (Search Strategy) dan Istilah Pencarian (Key Word)}

Dalam tahap pelaksanaan, dibutuhkan strategi pencarian dengan kata kunci seperti "Perencanaan Strategis TI"; "Peta Strategi TI" AND Universitas OR kampus; "Perancangan strategi TI: AND "Perguruan Tinggi". Adapun database yang digunakan dalam penelitian ini yaitu Google scholar, SINTA, Indonesian Scientific Journal Database (ISDJ), dan Research Gate (RG) yang memuat penelitian tentang PSTI perguruan tinggi di Indonesia. Selanjutnya artikel yang telah didapatkan diseleksi dengan menggunakan kriteria inklusi (penyertaan) dan ekslusi (pengecualian) untuk menentukan setiap artikel yang tidak selaras dengan pertanyaan penelitian. Kriterian inklusi dan ekslusi pada penelitian ini dapat dilihat pada Tabel 2.

Tabel 2. Kriteria Inklusi dan Ekslusi

\begin{tabular}{llll}
\hline No & \multicolumn{1}{c}{ Inklusi } & No & \multicolumn{2}{c}{ Eksklusi } \\
\hline 1. & $\begin{array}{l}\text { Semua literatur yang diterbitkan dalam } \\
\text { bahasa Inggris maupun Bahasa }\end{array}$ & Semua literatur yang diterbitkan tidak \\
Indonesia & $\begin{array}{l}\text { menggunakan bahasa Inggris maupun } \\
\text { Bahasa Indonesia } \\
\text { Semua literatur yang diterbitkan diluar }\end{array}$ \\
2. & $\begin{array}{l}\text { Semua literatur yang diterbitkan dari } \\
\text { periode 2010-2020 }\end{array}$ & 2. & $\begin{array}{l}\text { cakupan periode 2010-2020 } \\
\text { Semua literatur di luar kelompok PSTI di }\end{array}$ \\
3. Semua literatur yang termasuk ke dalam & 3. & $\begin{array}{l}\text { Indonesia. } \\
\text { kelompok PSTI di PT Indonesia. }\end{array}$
\end{tabular}

Adapun tahap akhir dari pelaksanaan SLR ini yaitu penilaian kualitas penelitian dan kelengkapan dari setiap jurnal yang disaring sesuai dengan kriteria inklusi dan ekslusi. Penilaian kualiatas penelitian berupa pernyataan "Ya" yang bernilai 2, pernyataan "Sebagian" bernilai 1, dan pernyataan "Tidak" bernilai 0. Pada Tabel 3 adalah pertanyaan yang digunakan dalam penilaian

Tabel 3. Kriteria Penilaian Kualitas Penelitian

\begin{tabular}{cll}
\hline ID Kualitas & \multicolumn{1}{c}{ Kriteria Penilaian Kualitas } & \multicolumn{1}{c}{ Jawaban } \\
\hline P1 & Ada penjelasan yang tujuan dan sasaran dari penelitian & Ya/Sebagian/ Tidak \\
P2 & Paper menjelaskan metode PSTI pada perguruan tinggi & Ya/Sebagian/ Tidak \\
P3 & Paper menjelaskan proses PSTI di perguruan tinggi & Ya/Tidak \\
P4 & Paper menjelaskan hasil PSTI di perguruan tinggi & Ya/Tidak \\
\hline
\end{tabular}

\section{Hasil dan Pembahasan}

Berdasarkan tahapan SLR seperti Gambar 1. Pertama, dilakukan proses pencarian artikel secara digital dan seleksi berdasarkan judul. Dengan menggunakan strategi pencaraian seperti yang 
dijelaskan di bagian 3.2 diperoleh total 130 artikel yang berasal dari Google scholar, direktori SINTA, ISDJ, dan RG seperti yang ditunjukkan pada Tabel 4.

Tabel 4. Rekapitulasi Hasil Pencarian Artikel

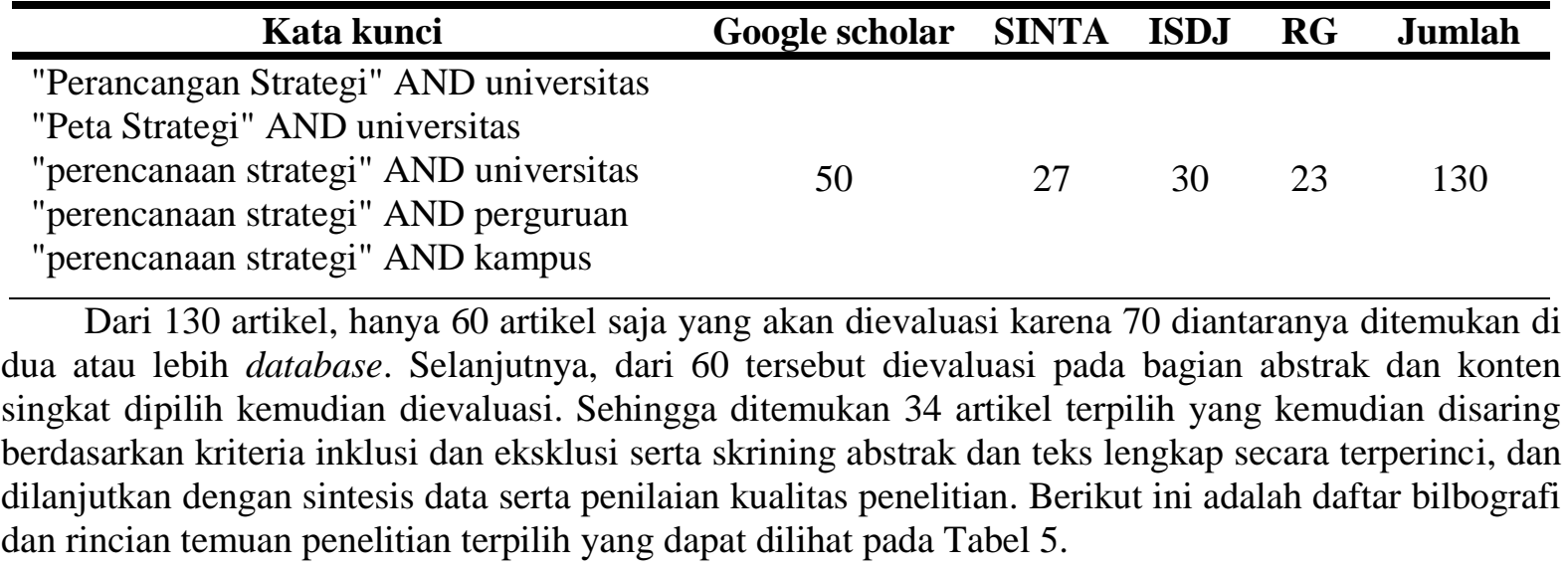

Tabel 5. Daftar Terpilih Yang Sesuai Dengan Kriteria

\begin{tabular}{|c|c|c|c|c|c|c|}
\hline $\begin{array}{c}\text { Kode } \\
\text { dan } \\
\text { Artikel }\end{array}$ & $\begin{array}{c}\text { Jenis } \\
\text { Publikasi }\end{array}$ & $\begin{array}{l}\text { Jumlah } \\
\text { Sitasi }\end{array}$ & Tujuan Penelitian & Framework & $\begin{array}{l}\text { Tools } \\
\text { Analisis }\end{array}$ & Nilai \\
\hline \multicolumn{7}{|c|}{ Jurnal Nasional Terindeks Sinta } \\
\hline P01 [4] & $\begin{array}{l}\text { Jurnal } \\
\text { Informatika }\end{array}$ & 1 & $\begin{array}{l}\text { Mensinergikan } \\
\text { perencanaan } \\
\text { pengembangan IT } \\
\text { dengan dengan visi } \\
\text { dan misi kampus }\end{array}$ & $\begin{array}{l}\text { Ward and } \\
\text { Peppard }\end{array}$ & $\begin{array}{l}\text { WOT, } \\
\text { PEST, } 5 \\
\text { Force } \\
\text { Porter, CSF } \\
\text { dan Mc } \\
\text { Farland's } \\
\text { Strategic } \\
\end{array}$ & 8 \\
\hline $\mathrm{P} 02$ [10] & $\begin{array}{l}\text { Jurnal } \\
\text { Teknologi } \\
\text { Terpadu }\end{array}$ & 3 & $\begin{array}{l}\text { Dapat memberi } \\
\text { gambaran ke depan } \\
\text { terhadap } \\
\text { pengembangan SI/TI }\end{array}$ & $\begin{array}{l}\text { Ward and } \\
\text { Peppard }\end{array}$ & $\begin{array}{l}\text { Porters Five } \\
\text { Forces, } \\
\text { SWOT, CSF } \\
\text { dan Value } \\
\text { Chain. }\end{array}$ & 8 \\
\hline P03 [12] & $\begin{array}{l}\text { Jurnal } \\
\text { Teknologi } \\
\text { Terpadu }\end{array}$ & 0 & $\begin{array}{l}\text { Untuk melakukan } \\
\text { perencanaan strategi } \\
\text { SI/TI yang disesuaikan } \\
\text { dengan visi, misi, } \\
\text { sasaran/tujuan, dan } \\
\text { proses bisnis }\end{array}$ & $\begin{array}{l}\text { Ward and } \\
\text { Peppard }\end{array}$ & $\begin{array}{l}\text { Porters Five } \\
\text { Forces, } \\
\text { SWOT, } \\
\text { CSF, Value } \\
\text { Chain, } \\
\text { McFarlan } \\
\text { Strategic } \\
\text { Analysis } \\
\end{array}$ & 8 \\
\hline P04 [11] & $\begin{array}{l}\text { Informatics } \\
\text { Journal }\end{array}$ & 0 & $\begin{array}{l}\text { Untuk menyediakan } \\
\text { peta strategi teknologi } \\
\text { informasi yang selaras } \\
\text { dengan tujuan } \\
\text { Universitas }\end{array}$ & $\begin{array}{l}\text { Cascading } \\
\text { Balance } \\
\text { Scorecard }\end{array}$ & & 7 \\
\hline P05 [5] & $\begin{array}{l}\text { Jurnal Riset } \\
\text { Sains dan } \\
\text { Teknologi }\end{array}$ & 1 & $\begin{array}{l}\text { Mengukur kinerja TI } \\
\text { di kampus }\end{array}$ & $\begin{array}{l}\text { IT Balanced } \\
\text { Scorecard }\end{array}$ & $\begin{array}{l}\text { SWOT, } \\
\text { TWOS, KPI }\end{array}$ & 8 \\
\hline P06 [15] & $\begin{array}{l}\text { CommIT } \\
\text { Journal }\end{array}$ & 10 & $\begin{array}{l}\text { Untuk menghasilkan } \\
\text { suatu bentuk usulan }\end{array}$ & $\begin{array}{l}\text { Ward and } \\
\text { Peppard }\end{array}$ & $\begin{array}{l}\text { PEST, BCG } \\
\text { Matriks, }\end{array}$ & 8 \\
\hline
\end{tabular}




\begin{tabular}{|c|c|c|c|c|c|c|}
\hline $\begin{array}{l}\text { Kode } \\
\text { dan } \\
\text { Artikel }\end{array}$ & $\begin{array}{c}\text { Jenis } \\
\text { Publikasi }\end{array}$ & $\begin{array}{c}\text { Jumlah } \\
\text { Sitasi }\end{array}$ & Tujuan Penelitian & Framework & $\begin{array}{l}\text { Tools } \\
\text { Analisis }\end{array}$ & Nilai \\
\hline & & & $\begin{array}{l}\text { perencanaan strategi } \\
\text { SI/TI. }\end{array}$ & & $\begin{array}{l}\text { Analisis } 5 \\
\text { Kekuatan } \\
\text { Porter, } \\
\text { SWOT, } \\
\text { Value } \\
\text { Chain, CSF } \\
\text { dan KPI. }\end{array}$ & \\
\hline P07 [2] & $\begin{array}{l}\text { Jurnal } \\
\text { Manajemen } \\
\text {, Teknik } \\
\text { Informatika } \\
\text {, dan } \\
\text { Rekayasa } \\
\text { Komputer } \\
\text { (MATRIK) }\end{array}$ & 1 & $\begin{array}{l}\text { Menyusun } \\
\text { perencanaan strategi } \\
\text { SI/TI pada STMIK } \\
\text { Bumigora Mataram, } \\
\text { yang selaras dengan } \\
\text { perencanaan strategi }\end{array}$ & $\begin{array}{l}\text { Ward and } \\
\text { Peppard }\end{array}$ & $\begin{array}{l}\text { PEST, } \\
\text { Porters Five } \\
\text { Forces, } \\
\text { Critical } \\
\text { SuccessFact } \\
\text { or (CSF), } \\
\text { Value } \\
\text { Chain, } \\
\text { McFarlan } \\
\text { Strategic } \\
\text { Analysis }\end{array}$ & 8 \\
\hline P08 [16] & $\begin{array}{l}\text { Jurnal } \\
\text { Teknologi } \\
\text { Informasi } \\
\& \\
\text { Komunikas } \\
\text { i Digital } \\
\text { Zone }\end{array}$ & 8 & $\begin{array}{l}\text { Untuk melakukan } \\
\text { analisis keselarasan } \\
\text { Sistem } \\
\text { Informasi/Teknologi } \\
\text { Informasi }\end{array}$ & $\begin{array}{l}\text { Ward and } \\
\text { Peppard }\end{array}$ & $\begin{array}{l}\text { SWOT, CSF } \\
\text { dan Analisa } \\
\text { Value Chain }\end{array}$ & 8 \\
\hline P09 [17] & $\begin{array}{l}\text { CommIT } \\
\text { Journal }\end{array}$ & 0 & $\begin{array}{l}\text { Mengoptimalkan peran } \\
\text { strategi SI/TI untuk } \\
\text { menciptakan } \\
\text { keunggulan kompetitif } \\
\text { STMIK IBBI }\end{array}$ & $\begin{array}{l}\text { Ward and } \\
\text { Peppard }\end{array}$ & $\begin{array}{l}\text { Porter's five } \\
\text { forces } \\
\text { analysis, } \\
\text { SWOT, } \\
\text { CSF, Value } \\
\text { Chain, dan } \\
\text { McFarlan. }\end{array}$ & 8 \\
\hline P10 [18] & $\begin{array}{l}\text { Jurnal Iptek } \\
\text { Terapan }\end{array}$ & 11 & $\begin{array}{l}\text { Membangun suatu } \\
\text { perencanaan } \\
\text { kebutuhan SI/TI agar } \\
\text { pembangunan SI/TI di } \\
\text { STIKes HTP dapat } \\
\text { dilakukan secara } \\
\text { terencana }\end{array}$ & $\begin{array}{l}\text { Ward and } \\
\text { Peppard }\end{array}$ & $\begin{array}{l}\text { PESTLE, } \\
\text { Teori Lima } \\
\text { Daya Porter, } \\
\text { CSF, Value } \\
\text { Chain, dan } \\
\text { analisa } \\
\text { McFarlan. }\end{array}$ & 8 \\
\hline P11 [1] & $\begin{array}{l}\text { Jurnal } \\
\text { Dokumenta } \\
\text { si dan } \\
\text { Informasi }\end{array}$ & 5 & $\begin{array}{l}\text { Agar Perpustakaan } \\
\text { Usakti memiliki } \\
\text { sebuah panduan } \\
\text { berupa strategi-strategi } \\
\text { yang harus dijalankan } \\
\text { di bidang TI. }\end{array}$ & $\begin{array}{l}\text { IT Balanced } \\
\text { Scorecard }\end{array}$ & $\begin{array}{l}\text { Analisis } \\
\text { SWOT }\end{array}$ & 8 \\
\hline P12 [19] & $\begin{array}{l}\text { Indonesian } \\
\text { Journal on } \\
\text { Computer } \\
\text { and }\end{array}$ & 6 & $\begin{array}{l}\text { Untuk } \\
\text { menggambarkan } \\
\text { keterkaitan strategi } \\
\text { TIK dengan strategi }\end{array}$ & $\begin{array}{l}\text { IT Balanced } \\
\text { Scorecard }\end{array}$ & $\begin{array}{l}\text { SWOT dan } \\
\text { KPI }\end{array}$ & 8 \\
\hline
\end{tabular}




\begin{tabular}{|c|c|c|c|c|c|c|}
\hline $\begin{array}{c}\text { Kode } \\
\text { dan } \\
\text { Artikel }\end{array}$ & $\begin{array}{c}\text { Jenis } \\
\text { Publikasi }\end{array}$ & $\begin{array}{c}\text { Jumlah } \\
\text { Sitasi }\end{array}$ & Tujuan Penelitian & Framework & $\begin{array}{l}\text { Tools } \\
\text { Analisis }\end{array}$ & Nilai \\
\hline & $\begin{array}{l}\text { Information } \\
\text { Technology }\end{array}$ & & $\begin{array}{l}\text { perguruan tinggi dan } \\
\text { mengusulkan } \\
\text { perencanaan peta } \\
\text { strategi }\end{array}$ & & & \\
\hline P13 [20] & $\begin{array}{l}\text { Journal of } \\
\text { Information } \\
\text { Systems }\end{array}$ & 1 & $\begin{array}{l}\text { Untuk memaksimalkan } \\
\text { operasionalnya SI/TI } \\
\text { sehingga selaras } \\
\text { dengan visi misi serta } \\
\text { strategi bisnis }\end{array}$ & $\begin{array}{l}\text { Metode } \\
\text { Tozer }\end{array}$ & $\begin{array}{l}\text { Value } \\
\text { Chain, CSF, } \\
\text { SWOT, } \\
\text { McFarlan } \\
\text { Grid, dan } \\
\text { Five Forces } \\
\text { Competitive } \\
\text { Model }\end{array}$ & 7 \\
\hline P14 [6] & $\begin{array}{l}\text { Jurnal Tata } \\
\text { Kelola dan } \\
\text { Kerangka } \\
\text { Kerja } \\
\text { Teknologi } \\
\text { Informasi }\end{array}$ & 1 & $\begin{array}{l}\text { Mengetahui dan } \\
\text { memastikan apakah } \\
\text { inisiatif-inisiatif TI } \\
\text { yang sudah, sedang } \\
\text { atau akan dilaksanakan } \\
\text { sudah sesuai dengan } \\
\text { strategi organisasi. }\end{array}$ & $\begin{array}{l}\text { SAMM } \\
\text { (Strategic } \\
\text { Alignment } \\
\text { Maturity } \\
\text { Model) }\end{array}$ & & 8 \\
\hline P15 [21] & $\begin{array}{l}\text { Journal of } \\
\text { Applied } \\
\text { Informatics } \\
\text { and } \\
\text { Computing } \\
\text { (JAIC) }\end{array}$ & 1 & $\begin{array}{l}\text { Membuat strategi } \\
\text { perencanaan IS/IT } \\
\text { yang dapat } \\
\text { memberikan masukan } \\
\text { pada pengambil } \\
\text { keputusan tentang } \\
\text { perlunya perencanaan } \\
\text { sistem informasi } \\
\text { strategi }\end{array}$ & & $\begin{array}{l}\text { Analisis } \\
\text { SWOT, } \\
\text { CSFdan } \\
\text { McFarlan } \\
\text { Matrix }\end{array}$ & 7 \\
\hline P16 [22] & $\begin{array}{l}\text { JISKa } \\
\text { (Jurnal } \\
\text { Informatika } \\
\text { Sunan } \\
\text { Kalijaga) }\end{array}$ & 0 & $\begin{array}{l}\text { Guna mendukung } \\
\text { institusi dalam } \\
\text { mempercepat } \\
\text { pencapaian visi dan } \\
\text { misi, sehingga } \\
\text { penerapan ICT } \\
\text { menjadi selaras } \\
\text { dengan kepentingan } \\
\text { bisnis institusi }\end{array}$ & $\begin{array}{l}\text { Balanced } \\
\text { Scrorecard }\end{array}$ & $\begin{array}{l}\text { Analisis } \\
\text { SWOT }\end{array}$ & 7 \\
\hline \multicolumn{7}{|c|}{ Prosiding } \\
\hline P17 [23] & $\begin{array}{l}\text { Prosiding } \\
\text { SINTAK } \\
2017\end{array}$ & 1 & $\begin{array}{l}\text { Untuk mendukung } \\
\text { pencapaian sasaran } \\
\text { strategik UPNVJ yang } \\
\text { terdapat pada Renstra. }\end{array}$ & $\begin{array}{l}\text { Kerangka } \\
\text { kerja } \\
\text { Zachman }\end{array}$ & $\begin{array}{l}\text { McFarlan } \\
\text { Strategic } \\
\text { Grid, } \\
\text { SWOT, } \\
\text { Value Chain }\end{array}$ & 7 \\
\hline P18 [7] & $\begin{array}{l}\text { Konferensi } \\
\text { Nasional } \\
\text { Sistem \& } \\
\text { Informatika } \\
2015\end{array}$ & 0 & $\begin{array}{l}\text { Untuk mencegah tidak } \\
\text { selarasnya } \\
\text { pemanfaatan sistem } \\
\text { informasi dan } \\
\text { kemudian hanya }\end{array}$ & $\begin{array}{l}\text { Pendekatan } \\
\text { TOGAF dan } \\
\text { Pemodelan } \\
\text { ADM }\end{array}$ & & 7 \\
\hline
\end{tabular}




\begin{tabular}{|c|c|c|c|c|c|c|}
\hline $\begin{array}{l}\text { Kode } \\
\text { dan } \\
\text { Artikel }\end{array}$ & $\begin{array}{c}\text { Jenis } \\
\text { Publikasi }\end{array}$ & $\begin{array}{c}\text { Jumlah } \\
\text { Sitasi }\end{array}$ & Tujuan Penelitian & Framework & $\begin{array}{l}\text { Tools } \\
\text { Analisis }\end{array}$ & Nilai \\
\hline & & & $\begin{array}{l}\text { menjadi program kerja } \\
\text { yang sifatnya tambal } \\
\text { sulam }\end{array}$ & & & \\
\hline P19 [9] & $\begin{array}{l}\text { Seminar } \\
\text { Nasional } \\
\text { Ilmu } \\
\text { Komputer } \\
\text { (SNIK } \\
\text { 2015) }\end{array}$ & 3 & $\begin{array}{l}\text { Membuat suatu model } \\
\text { perencanaan strategi } \\
\text { SI/TI yang mendukung } \\
\text { perencanaan bisnis }\end{array}$ & $\begin{array}{l}\text { Enterprise } \\
\text { Architecture } \\
\text { (EA) dengan } \\
\text { Framework } \\
\text { Togaf }\end{array}$ & & 6 \\
\hline P20 [24] & $\begin{array}{l}\text { Seminar } \\
\text { Nasional } \\
\text { Teknologi } \\
\text { Informasi } \\
\text { dan } \\
\text { Multimedia } \\
2016 \\
\end{array}$ & 4 & $\begin{array}{l}\text { Menyusun } \\
\text { perencanaan stategik } \\
\text { SI agar memiliki } \\
\text { mekanisme penerapan } \\
\text { SI/TI yang jelas guna } \\
\text { mencapai tujuan yang } \\
\text { optimal. }\end{array}$ & $\begin{array}{l}\text { Enterprise } \\
\text { Architecture } \\
\text { Planning } \\
\text { (EAP) }\end{array}$ & & 8 \\
\hline $\mathrm{P} 21[25]$ & $\begin{array}{l}\text { Prosiding } \\
\text { Seminar } \\
\text { Nasional } \\
\text { Manajemen } \\
\text { Teknologi } \\
\text { XVIII }\end{array}$ & 3 & $\begin{array}{l}\text { Membuat perencanaan } \\
\text { strategi SI dan TI yang } \\
\text { sesuai dan konsisten } \\
\text { terhadap visi, misi, dan } \\
\text { tujuan bisnis }\end{array}$ & $\begin{array}{l}\text { Ward and } \\
\text { Peppard }\end{array}$ & $\begin{array}{l}\text { PEST, } \\
\text { SWOT, } \\
\text { Value Chain } \\
\text { dan CSF }\end{array}$ & 8 \\
\hline P22 [26] & $\begin{array}{l}\text { Konferensi } \\
\text { Nasional } \\
\text { Teknologi } \\
\text { Informasi } \\
\text { dan } \\
\text { Aplikasiny } \\
\text { a }\end{array}$ & 0 & $\begin{array}{l}\text { Untuk perencanaan } \\
\text { strategi SI/TI yang } \\
\text { dapat membantu } \\
\text { mengoptimalkan peran } \\
\text { strategi SI/TI }\end{array}$ & & $\begin{array}{l}\text { SWOT, } \\
\text { TWOS, } \\
\text { PEST dan } \\
\text { McFarlan } \\
\text { Strategic } \\
\text { Grid }\end{array}$ & 5 \\
\hline P23 [27] & $\begin{array}{l}\text { Seminar } \\
\text { Nasional } \\
\text { Sistem } \\
\text { Informasi } \\
\text { Indonesia }\end{array}$ & 13 & $\begin{array}{l}\text { Membuat perencanaan } \\
\text { strategi SI/TI yang } \\
\text { diharapkan dapat } \\
\text { mendukung SI/TI } \\
\text { sehingga keuntungan } \\
\text { kompetitif dapat } \\
\text { dirasakan oleh } \\
\text { Perguruan Tinggi }\end{array}$ & $\begin{array}{l}\text { Ward and } \\
\text { Peppard }\end{array}$ & $\begin{array}{l}\text { CSF, Five } \\
\text { Porter, dan } \\
\text { McFarlan } \\
\text { Matrix }\end{array}$ & 6 \\
\hline P24 [28] & $\begin{array}{l}\text { Seminar } \\
\text { Nasional } \\
\text { Informatika }\end{array}$ & 8 & $\begin{array}{l}\text { Untuk mengetahui } \\
\text { seberapa besar tingkat } \\
\text { kematangan antara } \\
\text { strategi bisnis dan TI } \\
\text { untuk } \\
\text { mengembangkan ke } \\
\text { level kematangan yang } \\
\text { lebih tinggi }\end{array}$ & $\begin{array}{l}\text { Luftman IT- } \\
\text { Business } \\
\text { Alignment } \\
\text { Maturity } \\
\text { Model }\end{array}$ & & 7 \\
\hline \multicolumn{7}{|c|}{ Jurnal Tidak Terindeks Sinta } \\
\hline P25 [8] & Jurnal & 2 & Untuk menangkap & Cobit 5 , & Value & 7 \\
\hline
\end{tabular}




\begin{tabular}{|c|c|c|c|c|c|c|}
\hline $\begin{array}{l}\text { Kode } \\
\text { dan } \\
\text { Artikel }\end{array}$ & $\begin{array}{c}\text { Jenis } \\
\text { Publikasi }\end{array}$ & $\begin{array}{c}\text { Jumlah } \\
\text { Sitasi }\end{array}$ & Tujuan Penelitian & Framework & $\begin{array}{l}\text { Tools } \\
\text { Analisis }\end{array}$ & Nilai \\
\hline & $\begin{array}{l}\text { Sistem } \\
\text { Informasi }\end{array}$ & & $\begin{array}{l}\text { arah SI/TI di lembaga } \\
\text { pendidikan tinggi }\end{array}$ & $\begin{array}{l}\text { Ward and } \\
\text { Peppard }\end{array}$ & $\begin{array}{l}\text { Chain, } \\
\text { PEST dan } \\
\text { SWOT }\end{array}$ & \\
\hline P26 [29] & $\begin{array}{l}\text { Jurnal } \\
\text { Generik }\end{array}$ & 16 & $\begin{array}{l}\text { Untuk menemukan } \\
\text { gap antara TI yang } \\
\text { telah ada, pada yang } \\
\text { seharusnya disediakan } \\
\text { oleh PNJ berdasarkan } \\
\text { konsep Renstra TI. }\end{array}$ & $\begin{array}{l}\text { Ward and } \\
\text { Peppard }\end{array}$ & $\begin{array}{l}\text { CSF, Poter's } \\
\text { Five Forces, } \\
\text { Strategic } \\
\text { Alignment, } \\
\text { dan } \\
\text { McFarlan' } \\
\text { Strategic } \\
\text { Grid }\end{array}$ & 7 \\
\hline P27 [3] & $\begin{array}{l}\text { Jambura } \\
\text { Journal Of } \\
\text { Informatics }\end{array}$ & 0 & $\begin{array}{l}\text { Untuk mengevaluasi } \\
\text { dengan } \\
\text { membandingkan } \\
\text { pelaksanaan aktual } \\
\text { perencanaan } \\
\text { penyelarasan strategi } \\
\text { bisnis dan strategi TI }\end{array}$ & Cobit 5 & $\begin{array}{l}\text { Metode } \\
\text { Penilaian } \\
\text { SCAMPI }\end{array}$ & 7 \\
\hline P28 [30] & $\begin{array}{l}\text { Jurnal } \\
\text { Tecnoscien } \\
\text { za }\end{array}$ & 0 & $\begin{array}{l}\text { Untuk membangun } \\
\text { suatu perencanaan } \\
\text { kebutuhan SI/TI agar } \\
\text { pembangunan SI/TI } \\
\text { dapat dilakukan secara } \\
\text { teperencanaan }\end{array}$ & $\begin{array}{l}\text { Ward and } \\
\text { Peppard }\end{array}$ & $\begin{array}{l}\text { PEST, } \\
\text { SWOT, } \\
\text { CSF, } \\
\text { Analisa } \\
\text { Balanced } \\
\text { Scorecard } \\
\text { dan Value } \\
\text { Chain. }\end{array}$ & 7 \\
\hline P29 [31] & $\begin{array}{l}\text { Jurnal } \\
\text { Sebatik }\end{array}$ & 0 & $\begin{array}{l}\text { Membuat perencanaan } \\
\text { sistem informasi } \\
\text { strategi yang dapat } \\
\text { digunakan pada } \\
\text { perguruan tinggi, } \\
\text { sehingga bisa } \\
\text { dimanfaatkan sebagai } \\
\text { referensi } \\
\text { pengembangan sistem } \\
\text { informasi }\end{array}$ & $\begin{array}{l}\text { Ward and } \\
\text { Peppard }\end{array}$ & $\begin{array}{l}\text { Value } \\
\text { Chain, } \\
\text { SWOT, IT } \\
\text { Balanced } \\
\text { Scorecarad, } \\
\text { dan } \\
\text { McFarlan } \\
\text { Strategic } \\
\text { Grid. }\end{array}$ & 6 \\
\hline P30 [32] & $\begin{array}{l}\text { Jurnal } \\
\text { Telematika } \\
\text { MKOM }\end{array}$ & 1 & $\begin{array}{l}\text { Menyusun kerangka } \\
\text { kerja perencanaan } \\
\text { strategi SI/TI yang } \\
\text { dapat membantu } \\
\text { mengoptimalkan peran } \\
\text { strategi SI/TI }\end{array}$ & $\begin{array}{l}\text { Ward and } \\
\text { Peppard }\end{array}$ & $\begin{array}{l}\text { PEST, } 5 \\
\text { Kekuatan } \\
\text { Porter, } \\
\text { SWOT, } \\
\text { Value } \\
\text { Chain, dan } \\
\text { CSF. }\end{array}$ & 8 \\
\hline P31 [33] & $\begin{array}{l}\text { Jurnal } \\
\text { S@cies }\end{array}$ & 0 & $\begin{array}{l}\text { Untuk menghasilkan } \\
\text { suatu blueprint } \\
\text { rancangan SI/TI Yang } \\
\text { penting dan berguna }\end{array}$ & $\begin{array}{l}\text { Ward and } \\
\text { Peppard }\end{array}$ & $\begin{array}{l}\text { Value } \\
\text { Chain, } \\
\text { SWOT, } 5\end{array}$ & 7 \\
\hline
\end{tabular}




\begin{tabular}{|c|c|c|c|c|c|c|}
\hline $\begin{array}{c}\text { Kode } \\
\text { dan } \\
\text { Artikel } \\
\end{array}$ & $\begin{array}{c}\text { Jenis } \\
\text { Publikasi }\end{array}$ & $\begin{array}{c}\text { Jumlah } \\
\text { Sitasi }\end{array}$ & Tujuan Penelitian & Framework & $\begin{array}{l}\text { Tools } \\
\text { Analisis }\end{array}$ & Nilai \\
\hline & & & $\begin{array}{l}\text { bagi STMIK STIKOM } \\
\text { Indonesia }\end{array}$ & & $\begin{array}{l}\text { Forces } \\
\text { Model, } \\
\text { PEST dan } \\
\text { CSF. }\end{array}$ & \\
\hline P32 [34] & $\begin{array}{l}\text { Jurnal } \\
\text { Pengkajian } \\
\text { dan } \\
\text { Penerapan } \\
\text { Teknik } \\
\text { Informatika } \\
\text { (PETIR) }\end{array}$ & 2 & $\begin{array}{l}\text { Membuat perencanaan } \\
\text { strategi sistem } \\
\text { informasi yang sesuai } \\
\text { dengan organisasi } \\
\text { untuk mendukung } \\
\text { implementasi dalam } \\
\text { bentuk yang lebih } \\
\text { terpadu }\end{array}$ & $\begin{array}{l}\text { Ward and } \\
\text { Peppard }\end{array}$ & $\begin{array}{l}\text { SWOT, } \\
\text { Value } \\
\text { Chain, } \\
\text { PEST, } \\
\text { BCG, dan } \\
\text { Kekuatan } \\
\text { Poter }\end{array}$ & 7 \\
\hline P33 [35] & $\begin{array}{l}\text { Jurnal } \\
\text { Sarjana } \\
\text { Teknik } \\
\text { Informatika }\end{array}$ & 0 & $\begin{array}{l}\text { Pembuatan model } \\
\text { perencanaan strategi } \\
\text { SI/TI untuk } \\
\text { mendukung strategi } \\
\text { bisnis organisasi }\end{array}$ & $\begin{array}{l}\text { Tahapan } \\
\text { penelitian } \\
\text { The Planning } \\
\text { Process by } \\
\text { Anita } \\
\text { Cassidy. }\end{array}$ & $\begin{array}{l}\text { Analisis } \\
\text { SWOT }\end{array}$ & 8 \\
\hline P34 [36] & $\begin{array}{l}\text { Jurnal } \\
\text { Ilmiah } \\
\text { Komputer } \\
\text { dan } \\
\text { Informatika }\end{array}$ & 2 & $\begin{array}{l}\text { Mengetahui dan } \\
\text { memastikan apakah } \\
\text { inisiatif-inisiatif TI } \\
\text { yang sudah, sedang } \\
\text { atau akan dilaksanakan } \\
\text { sudah sesuai dengan } \\
\text { strategi organisasi. }\end{array}$ & $\begin{array}{l}\text { SAMM } \\
\text { (Strategic } \\
\text { Alignment } \\
\text { Maturity } \\
\text { Model) }\end{array}$ & & 7 \\
\hline
\end{tabular}

Dari hasil pencarian artikel yang telah terpilih pada Tabel 4, diperoleh jenis publikasi 16 artikel terindeks SINTA, 8 artikel prosiding dan 10 artikel tidak terindeks yang dipresentasikan dalam bentuk presentase pada Pie Chart seperti pada Gambar 2.

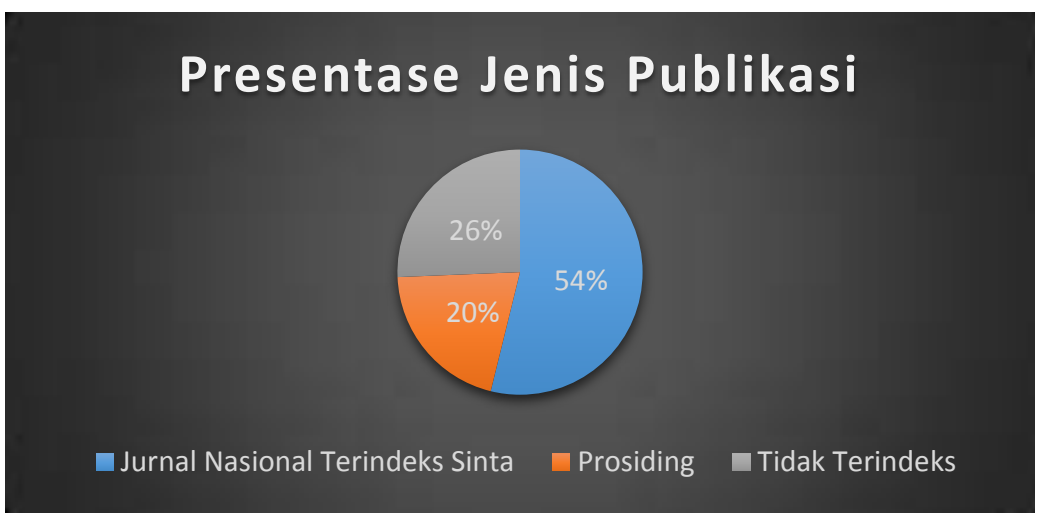

Gambar 2. Presentase Jenis Publikasi

Maka dalam sub bab di bawah ini akan dipaparkan dan dipresentasikan mengenai hasil pertanyaan penelitian pada Bagian 2.1 sebagai berikut:

\section{1 Apa Saja Topik Penelitian Mengenai Perencanaan Strategi IT?}

Berdarkan hasil pencarian artikel yang telah terpilih seperti pada Tabel 4, diperoleh temuan mengenai jenis penelitian perencanaan strategi IT berupa 2 topik penelitian yang meliputi:

1. Topik mengenai kegian perencanaan strategi IT pada perguruan tinggi. 
2. Topik mengenai tingkat keselarasan antara perencanaan strategi IT dan strategi bisnis perguruan tinggi.

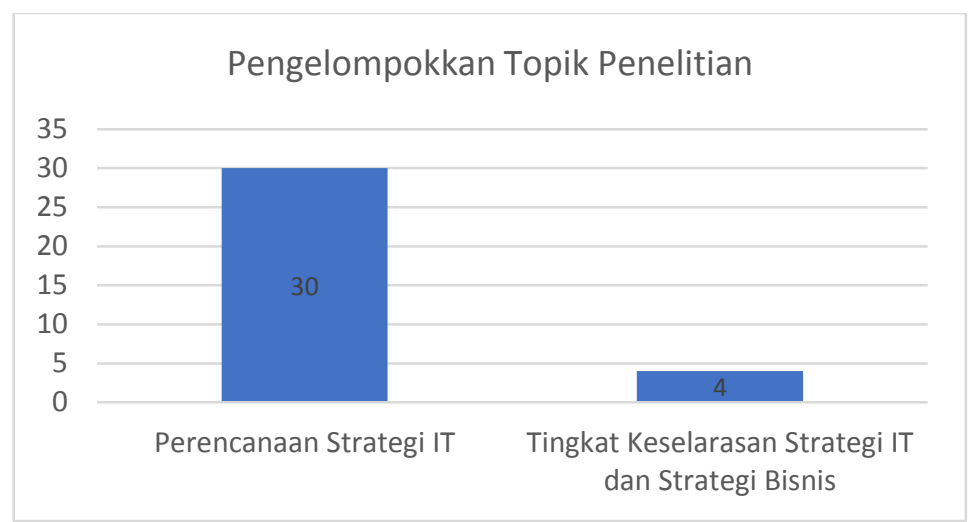

Gambar 3. Pengelompokkan Topik Penelitian

Berdasarkan temuan yang dapat dilihat pada Gambar 3, terdapat topik mengenai kegiatan perencanaan strategi IT pada perguruan tinggi sebanyak 30 artikel. Sedangkan penelitian mengenai tingkat keselarasan antara perencanaan strategi IT dan strategi bisnis pada perguruan tinggi hanya berjumlah 4 artikel. Yaitu pada artikel P24 menggunakan framework Luftman IT-Business Alignment Maturity Model, P27 menggunakan framework COBIT 5 serta P14 dan P34 menggunakan framework SAMM.

\section{2 Apa Saja Kerangka Kerja atau Framework yang Digunakan pada Perencanaan Strategi IT?}

Dibawah ini merupakan hasil pengelompokan kerangka kerja atau framework yang digunakan pada perencanaan strategi IT, yang ditunjukkan pada Gambar 4. Dari hasil yang dipaparkan pada Tabel 4, diperoleh temuan adanya 12 macam kerangka kerja yang digunakan pada penelitian terpilih. Terdapat artikel yang hanya menjelaskan mengenai tools analisis yang digunakan tanpa memaparkan atau menggunakan framework pada penelitiannya yaitu P15 dan P22. Dan terdapat artikel yang menggunakan 2 kerangka kerja yaitu P25 menggunakan COBIT 5 dan Ward and Peppard. Serta terdapat temuan bahwa kerangka kerja Ward and Peppard adalah kerangka kerja yang paling umum digunakan oleh para peneliti, berikutnya adalah IT Balanced Scorecard, kemudian Zachman, TOGAF dan SAMM.

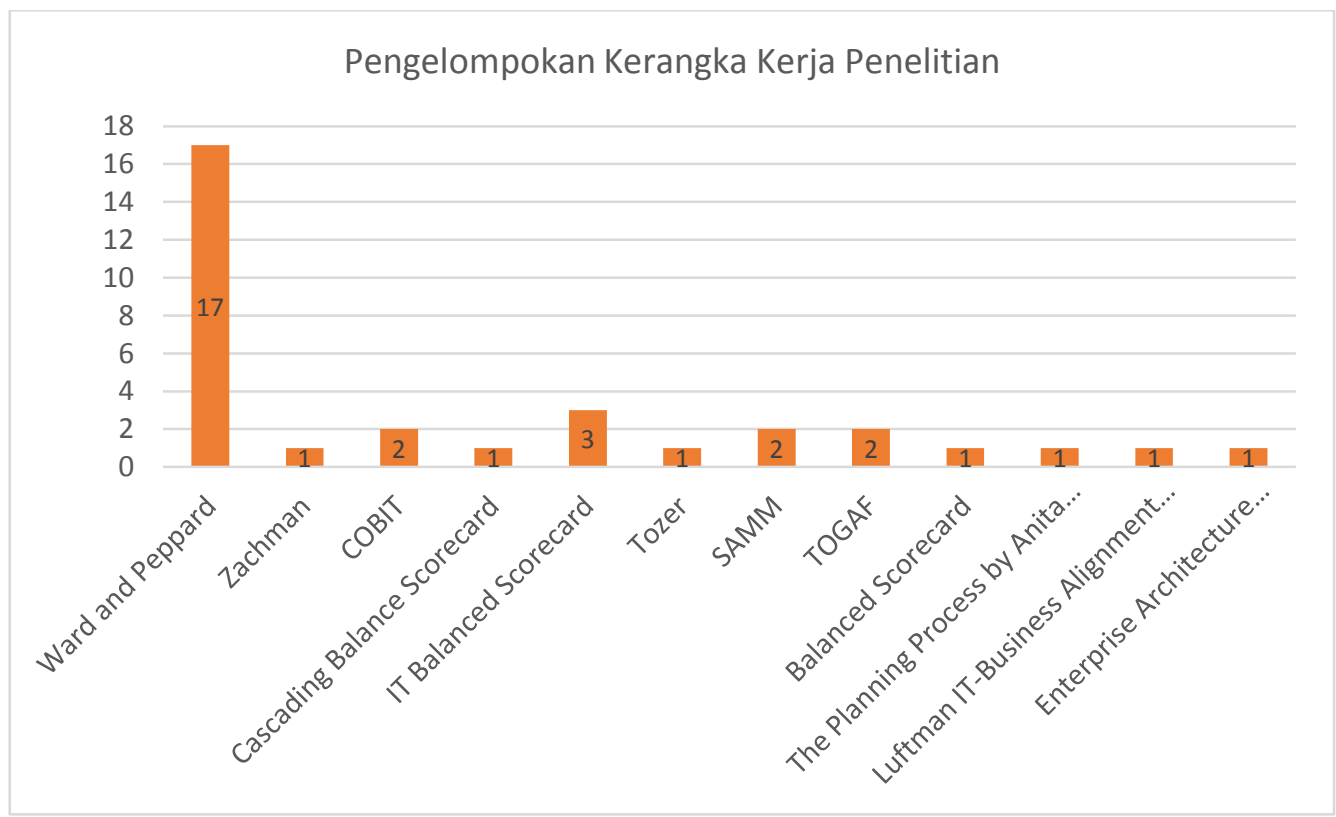

Gambar 4. Pengelompokan Kerangka Kerja Penelitian 


\section{3 Perguruan Tinggi Mana yang Dijadikan Objek Penelitian Perencanaan Strategi IT?}

Berikut ini adalah hasil pengelompokan perguruan tinggi yang digunakan sebagai objek penelitian pada perencanaan strategi IT pada artikel terpilih yang ditunjukkan pada Gambar 5.

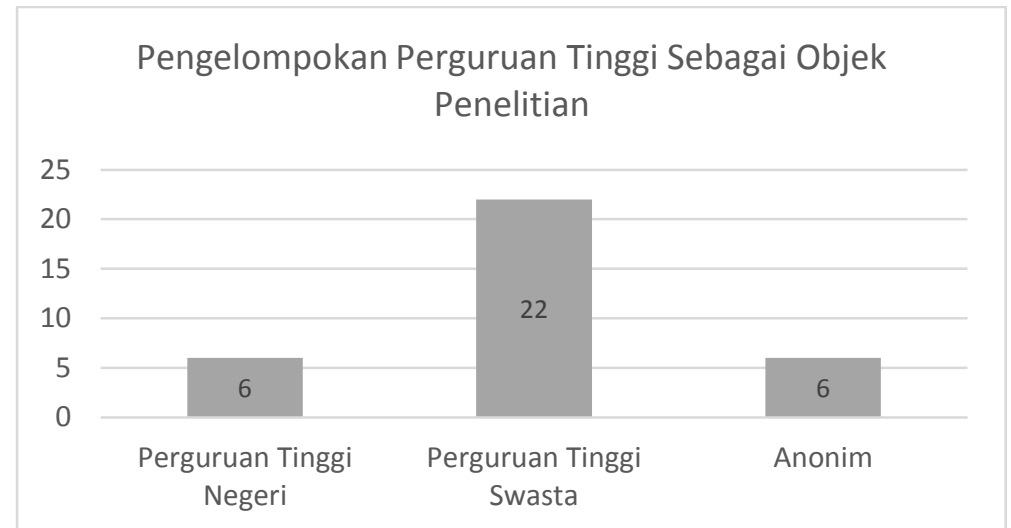

\section{Gambar 5. Pengelompokan Perguruan Tinggi Sebagai Objek Penelitian}

Dari hasil tersebut terdapat 6 artikel yang tidak menyebutkan dengan jelas objek penelitiannya, yaitu P15, P16, P23, P24, P33, dan P34. Serta terdapat temuan bahwa perguruan tinggi swasta adalah perguruang tinggi paling banyak dijadikan sebagai objek penelitian. Sedangkan penelitian mengenai perencanaan strategi TI perguruan tinggi negeri tergolong masih sedikit dilakukan.

\section{4 Aspek Apa Saja yang Dilakukan Penyusunan Perencanaan Strategi IT?}

Gambar 6 menampilkan hasil pengelompokan aspek yang dilakukan penyusunan perencanaan strategi IT pada penelitian terpilih yaitu aspek teknologi informasi dan sistem informasi.

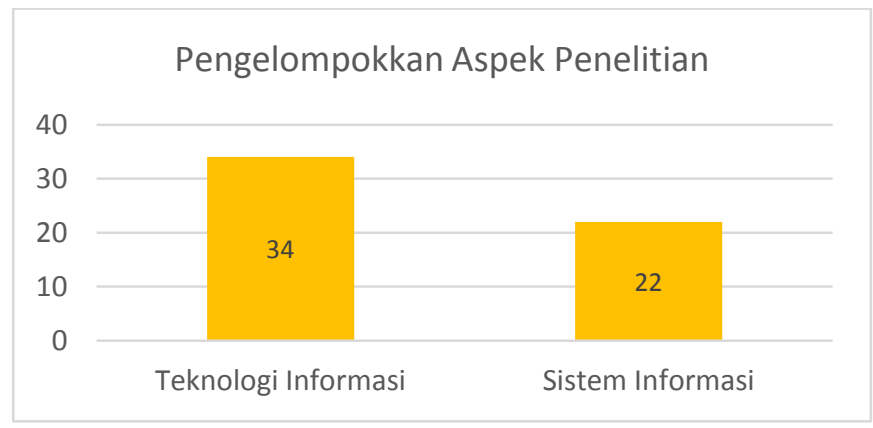

Gambar 6. Pengelompokkan Aspek Penelitian

Aspek teknologi informasi merupakan aspek yang paling banyak dilakukan penelitian dalam penyusunan perencanaan strategi TI yaitu berjumlah 34 penelitian. Terdapat 12 penelitian yang hanya berfokus pada perencanaan strategi teknologi informasi, dan 22 penelitian yang membahas perencanaan strategi sistem informasi dan teknologi informasi sekaligus. Dimana strategi sistem informasi digunakan untuk mendefinisikan kebutuhan organisasi mengenai informasi dan sistem yang dapat mendukung strategi bisnis. Sedangkan strategi teknologi informasi berfokus dalam mendukung cara untuk memenuhi kebutuhan organisasi dalam menggunakan teknologi informasi.

\section{5 Penelitian Apa yang Kurang Dilakukan dan Perlu Pengembangan?}

Berdasarkan Tabel 4 yang berisikan artikel terpilih, penelitian mengenai tingkat keselarasan antara perencanaan strategi IT dan strategi bisnis perguruan tinggi masih kurang dilakukan dan perlu pengembangan untuk mengetahui apakah perencanaan strategi IT yang telah ada selaras dengan strategi bisnis perguruan tinggi. Serta berdasarkan Gambar 5, penelitian mengenai perencanaan strategi IT pada perguruan tinggi negeri di Indonesia tergolong masih kurang dilakukan. 


\section{Kesimpulan}

Hasil penelitian ini ditampilkan pada Gambar 7, yang memaparkan mengenai jumlah topik penelitian, framework, objek penelitian, dan aspek penelitian yang paling banyak dilakukan pada penelitian perencanaan strategi teknologi informasi perguruan tinggi di Indonesia.

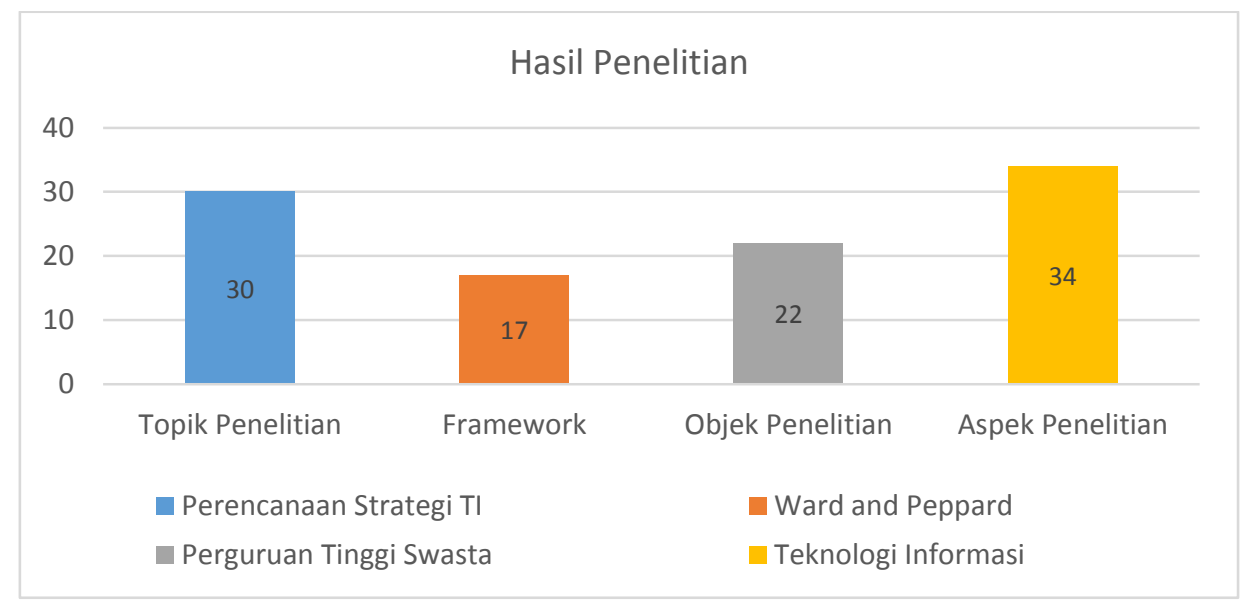

Gambar 7. Hasil Penelitian

Dari hasil penelitian pada artikel yang terpilih yang terdapat pada Tabel 4, didapatkan temuan mengenai jumlah penelitian yang paling banyak dilakukan, yaitu terdapat 30 artikel yang membahas topik penelitian mengenai kegiatan perencanaan strategi TI, 17 artikel yang menggunakan kerangka kerja Ward And Peppard, 22 perguruan tinggi swasta yang dijadikan objek penelitian, 34 artikel yang melakukan perencanaan strategi teknologi informasi sebagai aspek penelitian yang dapat dilihat pada Gambar 7. Selain itu, penelitian mengenai tingkat keselarasan antara perencanaan strategi IT dan strategi bisnis perguruan tinggi masih kurang dilakukan. Sehingga saran yang perlu dikembangkan adalah adanya peningkatan penelitian mengenai analisa keselarasan perencanaan strategi IT dan strategi bisnis perguruan tinggi, serta perlu adanya pembuatan perencanaan strategi IT untuk pembangunan teknologi informasi khususnya pada perguruan tinggi negeri di Indonesia yang tergolong masih sedikit dilakukan.

\section{REFERENSI}

[1] D. S. Handayani, "Perencanaan Strategis Teknologi Informasi Perpustakaan Universitas Trisakti," BACA: Jurnal Dokumentasi dan Informasi, vol. 34, pp. 147-166, 2013.

[2] A. Bachtiar and U. Hasanah, "Perencanaan Strategis SI/TI Pada Perguruan Tinggi (Studi Kasus: STMIK Bumigora Mataram)," MATRIK: Jurnal Manajemen, Teknik Informatika dan Rekayasa Komputer, vol. 16, pp. 45-54, 2017.

[3] S. N. Lahay and R. T. Dirgahayu, "Evaluasi Praktik Penyelarasan Strategi Bisnis Dan Strategi Teknologi Informasi Di Perguruan Tinggi," Jambura Journal of Informatics, vol. 2, pp. 4149, 2020.

[4] W. P. Putra, "Perancangan Strategi IT Politeknik Negeri Indramayu Menggunakan Pendekatan Ward and Peppard," Jurnal Informatika Ahmad Dahlan, vol. 9, pp. 103181, 2015.

[5] W. A. Prabowo and Y. Saintika, "Perancangan IT Balanced Scorecard dalam Penyusunan Strategic Map Perguruan Tinggi (Studi kasus: Institut Teknologi Telkom Purwokerto)," JRST (Jurnal Riset Sains dan Teknologi), vol. 2, pp. 27-36, 2018.

[6] H. Maulana, A. Hadiana, and I. Pangaribuan, "Pengukuran Tingkat Kematangan Keselarasan Strategi TI dan Bisnis (Studi Kasus Universitas Komputer Indonesia (UNIKOM))," Jurnal Tata Kelola dan Kerangka Kerja Teknologi Informasi, vol. 2, 2016.

[7] F. M. Ramlan, K. Kusrini, and H. Al Fatta, "Perencanaan Strategis SI/TI di Akademi Militer (Akmil) Magelang," Proceedings Konferensi Nasional Sistem dan Informatika (KNS\&I), 2015. 
[8] N. Abidin and F. Samopa, "Perencanaan Strategis SI/TI di Perguruan Tinggi Menggunakan COBIT 5 dan Ward and Peppard (studi kasus: Universitas Airlangga)," SISFO Vol 5 No 5, vol. 5, 2016.

[9] I. Hizbullah, E. Nugroho, and P. I. Santosa, "Model Perencanaan Strategis SI/TI Perguruan Tinggi Menggunakan Framework TOGAF (Studi Kasus STKIP KIE Raha)," in Seminar Nasional Ilmu Komputer (SNIK 2015), Semarang, 2015.

[10] A. Fatah, "IS/IT Strategic Planning Pada Universitas Balikpapan," JTT (Jurnal Teknologi Terpadu), vol. 3, 2015.

[11] Y. Muflihah and A. Hermanto, "Penerapan Cascading Balance Scorecard Dalam Pembuatan Peta Strategi TI (Studi Kasus: Direktorat Sistem Informasi Universitas 17 Agustus 1945 Surabaya)," INFORMAL: Informatics Journal, vol. 4, pp. 95-102, 2020.

[12] H. P. Rizanti and H. Saragih, "IT/IS Strategic Planning pada Sektor Edukasi Studi Kasus Universitas Bakrie," Jurnal Teknologi Terpadu (JTT), vol. 3, 2017.

[13] C. Okoli and K. Schabram, "Working Papers on Information Systems A Guide to Conducting a Systematic Literature Review of Information Systems Research," vol. 10, 2010.

[14] C. Adrian, R. Abdullah, R. Atan, and Y. Y. Jusoh, "Towards developing strategic assessment model for big data implementation: a systematic literature review," Int. J. Adv. Soft Compu. Appl, vol. 8, 2016.

[15] Maryani and S. Darudiato, "Perancangan Rencana Strategis Sistem Informasi Dan Teknologi Informasi (SI/TI): Studi Kasus STMIK XYZ," CommIT (Communication and Information Technology) Journal, vol. 4, pp. 77-85, 2010.

[16] W. Syafitri, "Perencanaan Strategi Sistem Informasi/Teknologi Informasi Universitas Lancang Kuning Menggunakan Metode Ward And Peppard," Digital Zone: Jurnal Teknologi Informasi dan Komunikasi, vol. 7, pp. 33-43, 2016.

[17] B. H. S. Hendry, "Perencanaan Strategis Sistem Informasi Dan Teknologi Informasi Pada STMIK IBBI," International Journal ofCommunication \& Information Technology(CommIT), vol. X, pp. 2010-2015, 2017.

[18] Y. Irawan, "Perencanaan Strategis SI/TI dengan Menggunakan Framework Ward and Peppard di STIKES Hang Tuah Pekanbaru," Jurnal Ilmu Komputer, vol. 6, pp. 25-32, 2017.

[19] B. K. Simpony and D. Riana, "Peta Strategi IT Balanced Scorecard di AMIK BSI Tasikmalaya," IJCIT (Indonesian Journal on Computer and Information Technology), vol. 1, 2016.

[20] A. Wijaya and A. Aliyanto, "Penerapan Metodologi Tozer dalam Perencanaan Strategis SI/TI pada Sekolah Tinggi Teknik Musi," Jurnal Sistem Informasi, vol. 9, pp. 95-100, 2013.

[21] A. B. Prasetyo, "Strategi Perencanaan Sistem Informasi Dan Teknologi Informasi di Lingkungan Perguruan Tinggi," Journal of Applied Informatics and Computing, vol. 2, pp. 24-28, 2018.

[22] L. Retnawati, "Perencanaan Strategis SI/TI Dengan Metode Analisa SWOT dan BSC Untuk Meningkatkan Daya Saing Di Universitas XYZ," JISKA (Jurnal Informatika Sunan Kalijaga), vol. 2, pp. 135-142, 2018.

[23] I. P. Solihin and M. B. Wibisono, "Perencanaan Strategik Sistem Informasi dan Teknologi Informasi (SI/TI) dengan Framework Zachman di Universitas Pembangunan Nasional Veteran Jakarta," 2017.

[24] A. Khumaidi, A. Suryana, and E. Ridhawati, "Perencanaan Strategi Sistem Informasi dan Teknologi Informasi pada Stmik Pringsewu dengan Menggunakan Metodologi Enterprise Architecture Planning (EAP)," Semnasteknomedia Online, vol. 4, pp. 4-11-1, 2016.

[25] E. Wahyuningtyas and F. Samopa, "Perencanaan Strategis Sistem Informasi/ Teknologi Informasi pada Universitas Wijaya Kusuma Surabaya," Tesis, Program Pasca Sarjana Institut Teknologi Sepuluh Nopember, Surabaya, 2013.

[26] T. Rahman, "Perencanaan Strategis Teknologi Informasi pada Akademik Manajemen Informatika dan Komputer (AMIK) Sigma," Konferensi Nasional Teknologi Informasi dan Aplikasinya, vol. 4, pp. 207-218, 2016. 
[27] R. I. Fariani, "Analisa Perencanaan Strategi Sistem Informasi dan Teknologi Informasi (SI/TI) Dengan Menggunakan Framework Ward \& Peppard di Perguruan Tinggi ABC," SESINDO 2014, vol. 2014, 2014.

[28] D. Pratama, "Pengukuran Keselarasan Strategi Teknologi Informasi dan Strategi Bisnis Dengan Model Luftman (Studi Kasus: Amik XYZ)," in Seminar Nasional Informatika (SNIf), 2017, pp. 102-107.

[29] I. Silanegara, B. A. Tama, and D. Nurhidayat, "Perencanaan Strategis Teknologi Informasi (Studi Kasus: Politeknik Negeri Jakarta)," Jurnal Generic, vol. 6, pp. 13-18, 2013.

[30] A. R. Perdanakusuma and A. I. Susanti, "Perencanaan Sistem Informasi Dan Teknologi Informasi: Studi Kasus Institusi XYZ," Jurnal TECNOSCIENZA, vol. 1, pp. 12-23, 2017.

[31] C. Sylvia and A. Angela, "Perencanaan Strategis Sistem dan Teknologi Informasi Pada STMIK-STIE Mikroskil Menggunakan Metode Ward \& Peppard," Sebatik, vol. 23, pp. 592603, 2019.

[32] L. Suryadi, "Perencanaan Strategis Sistem Informasi dan Teknologi Informasi (SI/TI): Studi Kasus Universitas Budi Luhur," Telematika MKOM, vol. 3, pp. 40-51, 2016.

[33] M. H. P. Swari and W. G. S. Parwita, "Perencanaan Strategis SI/TI Pada STMIK STIKOM Indonesia Dengan Metode Ward And Peppard," S@ CIES, vol. 6, pp. 31-40, 2015.

[34] A. Yani and M. S. Mardiyanto, "Perencanaan Strategis Teknologi Informasi: Studi Kasus Pada Perguruan Tinggi Lepisi Tangerang," PETIR: Jurnal Pengkajian dan Penerapan Teknik Informatika, vol. 12, pp. 101-110, 2019.

[35] M. G. A. Sulistiyatna and S. Handayaningsih, "Pembuatan Model Rencana Strategis SI/TI (Studi Kasus: Departemen Akademik Universitas XYZ)," Universitas Ahmad Dahlan, 2014.

[36] H. Maulana, "Pengukuran Tingkat Kematangan Keselarasan Strategi TI dan Bisnis (Studi Kasus Universitas XYZ)," KOMPUTA-Jurnal Komputer \& Informatika, vol. 4, 2016. 